\title{
PROGRAM INTERVENSI NARIMO ING PANDUM UNTUK MENINGKATKAN KESEJAHTERAAN PSIKOLOGIS KELUARGA PASIEN SKIZOFRENIA
}

\section{"NARIMO ING PANDUM" INTERVENTION PROGRAM TO ENHANCE PSYCHOLOGICAL WELL-BEING OF FAMILY CAREGIVER OF SCHIZOPHRENIC PATIENT}

\author{
Noor Hanafi Prasetyo \\ M.A. Subandi \\ Fakultas Psikologi Universitas Gadjah Mada Yogyakarta \\ Email: prasetyo.psi@gmail.com; subandi@ugm.ac.id
}

\begin{abstract}
This study aimed at understanding the effect of Narimo Ing Pandum (NIP) intervention program to enhance psychological well-being of family caregiver of schizophrenic patient. NIP was developed based on Javanese values of kesabaran (patience), kebersyukuran (gratitude) and narimo (acceptance). The respondents of were two family caregivers of schizophrenic patient. This study employed a quasi experimental with a single case A-B-A design. Two instruments were used: NIP Scale and Psychological well-being scale. Visual inspection and qualitative data analysis were used. The result indicated that NIP intervention program increased the psychological well-being of family caregiver of schizophrenia marked by the increasing NIP attitude of the two participants before and after the intervention. Although their psychological well-being decreased in the follow-up phase, their NIP attitude was stable.
\end{abstract}

Keywords : Narima Ing Pandum, psychological well-being, family caregiver

\begin{abstract}
ABSTRAK
Penelitian ini bertujuan untuk mengetahui pengaruh program intervensi Narimo Ing Pandum (NIP) untuk meningkatkan kesejahteraan psikologis keluarga pasien skizofrenia. NIP dikembangkan berdasarkan nilainilai Jawa yaitu kesabaran, kebersyukuran dan narimo. Responden penelitian ini adalah 2 keluarga yang merawat penderita gangguan skizofrenia. Pendekatan penelitian quasi experiment dengan desain kasus tunggal A-B-A design diterapkan dalam penelitian ini. Ada dua instrument yang digunakan, yaitu Skala NIP dan Skala Kesejahteraan Psikologis. Analisis data digunakan Visual inspection dan analisis kualitatif. Hasil analisis data menunjukkan bahwa intervensi NIP dapat meningkatkan kesejahteraan psikologis keluarga yang merawat anggota keluarga yang mengalami gangguan skizofrenia. Meskipun dalam tahap tindak lanjut ada sedikit penurunan kesejahteraan psikologis, tapi sikap narimo ing pandum mereka masih stabil.
\end{abstract}

Keywords : Narima Ing Pandum, kesejahteraan psikologis, perawat keluarga

Gangguan jiwa adalah suatu kondisi kesehatan yang menyebabkan gangguan dalam proses berpikir, suasana hati, maupun perilaku (McKenzie, 2006). Salah satu gangguan jiwa berat adalah skizofrenia (Hawari, 2003). Skizofrenia meru- 
pakan gangguan psikiatrik yang paling banyak menimbulkan permasalahan, baik bersifat medis, psikologis, maupun sosial serta berdampak pada munculnya disfungsi sosial, pekerjaan, dan perawatan (Puspasari, 2012). Data di lapangan menyebutkan bahwa sekitar $70 \%$ sampai 85\% ODS kembali ke lingkungan tempat tinggalnya dan mengandalkan bantuan perawatan family caregiver (Grandon, Jenaro, \& Lemos, 2008). Menurut Schene, Wijngaarden, dan Koeter (1998), keberadaan ODS (orang dengan skizofrenia) akan menimbulkan konsekuensi cukup berat pada family caregiver.

Dampak nyata yang harus dihadapi oleh family caregiver antara lain adalah hilangnya kesempatan dan produktivitas mencari nafkah karena harus merawat penderita secara terus menerus, tingginya biaya perawatan yang harus ditanggung keluarga serta stigma sosial yang harus dihadapi (Syamsuri, 2011; Ambikile \& Outwater, 2012). Schultz dan Sherwood (2008) mengungkapkan bahwa proses pendampingan yang sudah berlangsung lama dapat menimbulkan pengalaman stres yang kronis dan menciptakan ketegangan fisik serta psikologis. Hal ini dapat menjadi beban psikologis tersendiri dalam melakukan tugas-tugas pendampingan (Koeswardhani, 2011).

Beban yang harus ditanggung selama melakukan pendampingan terhadap ODS dimaknai berbeda oleh masingmasing family caregiver. Perbedaan ini dipengaruhi oleh sikap penerimaan yang berdampak pada pola keunikan, proses interaksi dan adaptasi terhadap situasi di lingkungannya (Dorian, Gracia, Lopez \& Hernandez, 2008). Menurut Bloch, Scmukler, Herrman, dan Colussa (1995), kurangnya sikap penerimaan tersebut akan meningkatkan kondisi stressful pada family caregiver yang berdampak pada menurunnya kesejahteraan psikologis. Program intervensi terhadap family caregiver perlu dilakukan untuk meningkatkan sikap penerimaan terhadap situasi dan kondisi selama melakukan perawatan sehingga kesejahteraan psikologisnya meningkat (Bloch et al, 1995).

Kesejahteraan psikologis tampak dari cara seseorang bersikap dan menunjukkan emosi positif dalam hidupnya (Huppert, Baylis, \& Keverne, 2005). Menurut Ryff (1989), kesejahteraan psikologis ditandai oleh adanya sikap positif, baik terhadap diri sendiri maupun orang lain. Individu yang sejahtera secara psikologis adalah mereka yang mampu membuat keputusan sendiri, mengatur perilaku mereka sendiri dan kemudian memilih atau membentuk lingkungan yang sesuai dengan kebutuhannya. Mereka memiliki tujuan yang dapat membuat hidup menjadi lebih bermakna serta senantiasa berusaha untuk mengembangkan diri secara penuh (Ryff \& Keyes, 2002). Dengan demikian, kesejahteraan psikologis merupakan gambaran dari kesehatan psikologis seseorang berdasarkan kriteria psikologi positif.

Ryff (1989) menjabarkan bahwa kesejahteraan psikologis merupakan istilah yang digunakan untuk menggambar- 
kan kesehatan psikologis individu berdasarkan pemenuhan kriteria fungsi psikologi positif. Kriteria psikologi positif antara lain (1) penerimaan diri, (2) hubungan positif dengan orang lain, (3) kemandirian, (4) penguasaan lingkungan, (5) tujuan hidup, (6) pengembangan diri. Model kesejahteraan psikologis yang diungkapkan oleh Ryff telah dikaji oleh banyak penelitian, di mana masing-masing dimensi saling berhubungan dalam konstruk kesejahteraan psikologis.

Talwar dan Matheiken (2010) mengatakan bahwa pemberian program intervensi bagi family caregiver harus disesuaikan dengan kondisi dan latar belakang budaya tempat mereka tinggal. Sikap dan strategi coping family caregiver akan berbeda antara satu budaya dengan budaya lainnya. Hal tersebut tergantung pada tata nilai sosial serta budaya tempat dimana ODS dan family caregiver tinggal (Talwar dkk, 2010). Dengan demikian, pemberian program intervensi seharusnyalah menggunakan konsep kultural serta disesuaikan dengan latar belakang budaya setempat (Matsumoto, 2004).

Pelaksanaan program intervensi yang disesuaikan dengan latar belakang budaya klien mempunyai beberapa manfaat. Menurut White, Connoly Gibbons, dan Scamberger (2006), manfaat tersebut antara lain (1) mempermudah penyatuan kesepahaman antara fasilitator dan partisipan berkenaan dengan masalah yang sedang dihadapi, (2) memunculkan rasa nyaman dan tenang pada partisipan terutama pada tahap building rapport, (3) menjadikan partisipan antusias mengikuti program intervensi ketika merasa fasilitatornya satu budaya dengan dirinya.

Ciri khas sebuah suku adalah adanya nilai-nilai luhur yang melekat pada orang-orang dalam suku tersebut. Hal ini akan bertahan dan kemudian berkembang menjadi sebuah bangunan kepribadian bersama (Rahardjo, 2005). Kesadaran bersama masyarakat Jawa meyakini bahwa budaya Jawa mempunyai nilai-nilai yang mendasari kepribadian orang dan masyarakatnya (Casmini, 2011). Salah satu nilai budaya yang dikenal dan diadopsi secara luas oleh masyarakat Jawa sampai sekarang adalah sikap Narima Ing Pandum (NIP) (Endraswara, 2012). Menurut Koentjaraningrat (1990), sikap NIP yang berkaitan erat dengan aspek spiritual telah melahirkan sebuah nilai fundamental dan tidak lekang ditelan jaman. NIP adalah sebuah sikap penerimaan secara penuh terhadap berbagai kejadian pada masa lalu, masa sekarang serta segala kemungkinan yang bisa terjadi pada masa yang akan datang. Hal ini merupakan upaya untuk mengurangi kekecewaan apabila yang terjadi kemudian ternyata tidak sesuai dengan apa yang diharapkan (Endraswara, 2012; Soesilo, 2003; Rachmatullah, 2010). Sikap NIP menjadi ciri yang cukup kuat pada pribadi individu dengan latar belakang budaya Jawa (Martiarini, 2012).

Sikap NIP tidak dapat disebut sebagai sikap fatalistik. Menurut Mangkunegara I (Fananie, 2005), sikap NIP harus 
didahului dengan obah (usaha) untuk menerima dan menjalani pepesthen Gusti (takdir Tuhan) secara ikhlas sebagaimana kodrat diciptakannya manusia. Sikap NIP menuntun manusia untuk senantiasa bersyukur serta sabar dalam menerima berbagai macam cobaan kehidupan (bebendhu) (Endraswara, 2012; Suratno \& Asiyanto, 2009; Hardjowirogo, 1989; Sastroamidjojo, 1972). Pada saat individu dipenuhi oleh rasa narima, sukur dan terima kasih, maka tubuh akan menjadi rileks. Kondisi rileks dapat memberikan pemijatan halus pada berbagai kelenjar tubuh, menurunkan produksi kortisol dalam darah serta menyeimbangkan pengeluaran hormon sehingga memberikan keseimbangan emosi dan ketenangan pikiran (Davis, Eshelman \& Mckay, 1995). Sebagai hasilnya, manusia akan mendapatkan ketentraman serta kemampuan menyesuaikan diri terhadap dinamisasi kehidupan yang kemudian melahirkan kebahagiaan (Casmini, 2011; Dharmawati, 2011; Endraswara, 2012). Menurut Ryff dan Keyes (2002), kebahagiaan merupakan outcome variable dari kesejahteraan psikologis (psychological well-being).

Sikap NIP terdiri atas beberapa fondasi nilai, yaitu sukur (kebersyukuran), sabar (kesabaran) dan narima (penerimaan) (Hardjowirogo, 1989; Soesilo, 2003; Fananie, 2005; Mulyana, 2006; Renoati, 2006; Widayat, 2006; Darmanto, 2007; Suratno \& Astiyanto, 2009; Endraswara, 2012). Fondasi sukur, sabar, dan narima yang kuat menyebabkan sikap
NIP menjadi mudah terpatri pada jiwa seseorang sehingga dapat menerima segala keadaan dengan lapang dada serta tidak terjebak memikirkan pengalaman pahit masa lalu dan ketidakpastian masa depan (Endraswara, 2012; Mulyana, 2006; Widayat, 2006).

Syukur (sukur) merupakan sebuah bentuk emosi atau perasaan positif atas limpahan anugrah yang telah diterima, kemudian berkembang menjadi suatu sikap serta kebiasaan dan akhirnya memengaruhi seseorang dalam bereaksi terhadap lingkungannya (Emmons \& McCullough, 2003). Sabar merupakan sebuah sandaran nilai ketahanan yang banyak digunakan ketika orang menghadapi persoalan psikologis, misalnya menghadapi situasi yang penuh tekanan (stress), menghadapi persoalan, musibah atau ketika sedang mengalami kondisi emosi marah (Subandi, 2011). Sedangkan narima adalah sebuah keyakinan bahwa manungsa sakdrema nglakoni urip (manusia hanya sekedar menjalani hidup) dan Gusti kang wenang nemtoake (Tuhan yang berwenang menentukan) (Aksan, 1995; Darmanto, 2007; Suratno \& Astiyanto, 2009). Sikap NIP sudah sangat melekat dalam kesadaran sosial dan sangat cocok diinternalisasikan pada masyarakat Jawa (Koentjaraningrat, 1990).

Salah satu usaha untuk menginternalisasikan sikap NIP adalah melalui program psikoedukasi. Berbagai penelitian telah menunjukkan keuntungan psikoedukasi, yaitu meningkatkan sikap penerimaan, strategi koping, pemecahan 
masalah, menurunkan stres, dan membawa perubahan positif (Oshodi, Adeyemi, Alna \& Umeh, 2012), membantu mengurangi beban, meningkatkan kualitas pendampingan fisik dan mental pendamping (Navidian, Kemansaravi, \& Rigi, 2012), meningkatkan fungsi sosial, kepuasan hidup, pengetahuan, harapan serta keberdayaan pada ODS, menurunkan distress, peningkatan well-being dan fungsi keluarga pendamping secara keseluruhan (Drapalsky, Leith, \& Dixon, 2009).

Hal ini juga dapat diperkuat dengan memberikan pengelolaan stres dan teknik coping yang lain, seperti pendekatan naratif dan meditasi (Greenberg, 2002; Stern, Doolan, Staples, Szmukler \& Eisler, 1999). Melalui pendekatan naratif, partisipan didorong untuk menceritakan pengalaman yang berkaitan dengan keadaan yang selama ini dihadapinya. Hal ini dapat membantu pendamping untuk mengenali kekuatan diri, potensi, serta berbagai kemungkinan untuk bertindak dan tumbuh (Stern dkk, 1999). Sedangkan meditasi dapat membantu partisipan untuk secara sadar menjadi rileks. Hal tersebut menyebabkan pikiran berubah menjadi tenang, rileks, dan terpusat (Broto, 1994; Davis, Strasburger \& Brown, 2007; Endraswara, 2012; Navidian, Kemansaravi, \& Rigi, 2012).

Pemberian teknik semadi (meditasi) di beberapa sesi didasarkan pada nilai budaya Jawa eneng, ening dan eling. Soesilo (2003) mengatakan bahwa saat menghadapi goncangan, musibah, mau- pun tekanan kehidupan hendaknya belajar untuk bersemadi (meditasi) dengan eneng (diamnya raga), ening (heningnya cipta) dan eling (sabar, sukur dan menyandarkan diri pada kuasa Tuhan). Menurut Endaraswara (2012), ada banyak cara semadi (meditasi), seperti tapa, zen, relaksasi, dan yoga. Semuanya bermuara pada olah cipta dan rasa yang melahirkan ketenangan serta kebahagiaan.

Semadi (meditasi) berarti (1) melihat ke dalam diri secara proporsional, (2) menumbuhkan kesadaran diri agar mengetahui kekurangan dan kelebihan, (3) membayangkan keadaan teduh, indah dan nyaman sehingga lahirlah ketenteraman, (4) melepaskan pikiran dan perasaan yang mengganggu sehingga lahirlah kebahagiaan (Endraswara, 2012). Pemberian teknik semadi (meditasi) dilakukan karena family caregiver telah menghadapi kehidupan yang penuh dengan tekanan. Diperlukan teknik penurunan stess yang disesuaikan dengan latar belakang budaya mereka.

Berdasarkan kajian di atas, hipotesis yang diajukan dalam penelitian ini adalah bahwa program intervensi NIP dapat meningkatkan kesejahteraan psikologis family caregiver ODS.

\section{METODE PENELITIAN}

\section{Desain Penelitian}

Desain penelitian yang digunakan adalah eksperimen single case A-B-A design. Pada kedua partisipan itu diberikan program intervensi yang diberi nama Narimo Ing Pandum (NIP). Modul 
NIP dikembangkan oleh peneliti dengan mengacu pada konsep yang telah dijelaskan di atas.

\section{Subjek Penelitian}

Partisipan dalam penelitian ini adalah 2 orang family caregiver dari pasien ODS yang pernah dirawat di RSJ Ghrasia Yogyakarta. Berdasarkan data yang didapatkan dari RSJ, peneliti berkoordinasi dengan psikolog puskesmas untuk selanjutnya berkunjung ke rumah beberapa family caregiver ODS, memberikan penjelasan tentang penelitian dan menawarkan kesediaan menjadi partisipan. Family caregiver ODS yang menyatakan kesediaannya, diberikan penjelasan prosedur yang harus diikuti, hak dan resiko. Dari beberapa calon partisipan yang bersedia, akhirnya diperoleh 2 orang yang menandatangani lembar kesediaan atau informed consent, yaitu partisipan yang diberi inisial EN dan SR.

\section{Metode Pengumpulan Data}

Metode pengumpulan data dilakukan dengan meminta partisipan untuk mengisi Skala NIP yang terdiri atas aspek sukur, sabar dan narima. Skala ini berjumlah 18 aitem yang disusun oleh Renoati (2006). Skala NIP berbentuk skala likert dengan lima alternatif jawaban yang menunjukkan tingkat kesesuaian partisipan terhadap pernyataan. Selain Skala NIP, pada partisipan penelitian juga diberikan Skala Kesejahteraan Psikologi yang disusun oleh peneliti berdasarkan teori kesejahteraan psikologis dari Ryff
(1989) serta Ryff dan Keyes (2002).

Selain dua skala di atas partisipan diminta menulis buku harian yang terdiri atas dua bagian. Bagian pertama berupa media untuk menggambarkan pengalaman serta perasaan partisipan setiap hari. Sedangkan bagian kedua berisi ceklis sikap NIP selama mendampingi ODS setiap hari. Ceklis ini disusun berdasarkan tiga aspek dalam intervensi NIP, yaitu sabar, syukur dan narima. Ceklis terdiri atas 9 aitem dengan skor pilihan jawaban antara 1 sampai 5 . Semakin tinggi skor yang diperoleh menunjukkan sikap NIP yang lebih tinggi. Buku ini diisi partisipan setiap hari selama mengikuti penelitian.

\section{Intervensi}

Program Intervensi NIP diberikan melalui kunjungan rumah secara individual. Hal ini ditujukan agar fasilitator dapat menyesuaikan dengan situasi dan kondisi masing-masing partisipan sehingga proses intervensi dapat berjalan lebih optimal. Program ini merupakan psikoedukasi singkat yang terdiri atas lima pertemuan dengan materi psikoedukasi skizofrenia, psikoedukasi sikap NIP (psikoedukasi nilai sukur, psikoedukasi nilai sabar, psikoedukasi nilai narima) dan latihan semedi (meditasi).

\section{Teknik Analisis Data}

Metode analisis data dari hasil skala kesejahteraan psikologis, skala NIP dan ceklis sikap NIP harian dilakukan melalui visual inspection untuk mengetahui perubahan yang terjadi pada partisipan 
sebelum, selama dan setelah intervensi (follow up). Analisis data lintas waktu sebelum, selama dan setelah intervensi serta analisis deskriptif bertujuan untuk memahami proses dan kemajuan yang dicapai oleh masing-masing partisipan.

\section{HASIL PENELITIAN}

Hasil analisis data disajikan di bawah ini secara individual untuk kedua partisipan.

\section{Partisipan EN}

Partisipan EN telah merawat suaminya yang mengalami gangguan skizofrenia (ODS) sejak 15 tahun yang lalu. ODS bekerja sebagai kuli bangunan di Tanjung Priok, Jakarta Utara. Setelah beberapa bulan bekerja, ODS pulang dalam kondisi bingung. la tidak ingat dengan dirinya dan keluarga. ODS menjadi mudah marah dan mengaku sebagai pewaris tahta kerajaan Gunung Merapi.

EN meyakini bahwa ODS telah kerasukan jin. Tetangga kanan kirinya juga meyakini hal yang sama. EN kemudian membawa ODS ke seorang kyai pengasuh pondok pesantren. Menurut EN, ODS menjadi tenang selama di pesantren, tetapi kembali kambuh setelah pulang ke rumah. Jika sedang kambuh, ODS sering memarahi dan memukul EN. ODS juga suka merusak barang-barang tetangganya. $\mathrm{Hal}$ ini membuat EN merasa sedih, malu sekaligus kesal. EN harus mengganti rugi barang-barang yang telah dirusak oleh ODS. EN kadang harus berhutang untuk mengganti barang-barang tersebut.

Usaha yang dilakukan EN untuk mengatasi hal ini adalah dengan melarang ODS pergi ke luar rumah. la juga jarang berbicara terlalu lama dengan tetanggatetangganya. Di sisi lain, EN harus pergi ke sawah setiap hari untuk mburuh tani. Dialah yang selama ini menjadi tulang punggung keluarga. Menurut EN, perasaan sedih, malu, jengkel dan bingung hanya bisa dipendam. la lebih memilih tidur untuk melupakan masalahnya. Perasaan tersebut muncul dalam ungkapannya, "pun ... nek kedaden koyo niki ajeng crito kalih sinten malih... kalih tiyang-tiyang pun isin..isane nggih ming ngampet...mending tinggal tilem mangke rak kurang susahe" (sudahlah ... kalau keadaan seperti ini mau cerita ke siapa lagi... dengan orang-orang rasanya malu... bisanya hanya memendam perasaan, mendingan tidur saja supaya hilang sedihnya).

Analisis perubahan kondisi EN melalui visual inspection menunjukkan adanya peningkatan kesejahteraan psikologis selama pelaksanaan intervensi dari kategori rendah menjadi sedang, namun kembali menurun menjadi kategori rendah pada saat tindak lanjut. 


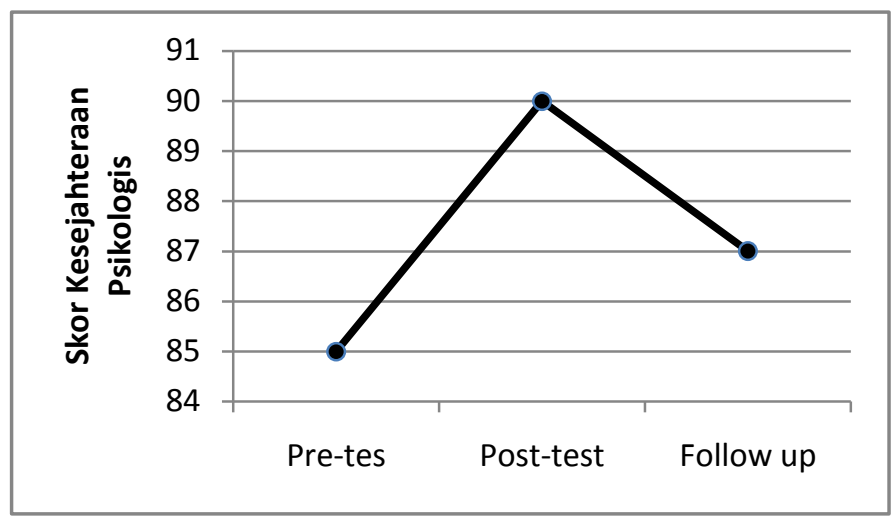

Gambar 1. Grafik Skor Kesejahteraan Psikologis EN

Perubahan tingkat kesejahteraan psikologis selaras dengan sikap NIP partisipan. Partisipan menunjukkan peningkatan sikap NIP dari kategori sangat rendah pada saat prates menjadi kategori sedang pada pascates tetapi menurun menjadi kategori rendah pada saat tindak lanjut.

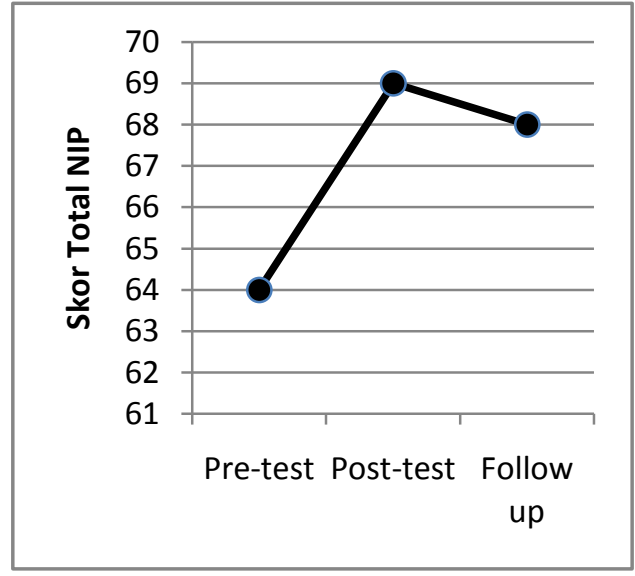

Gambar 2a

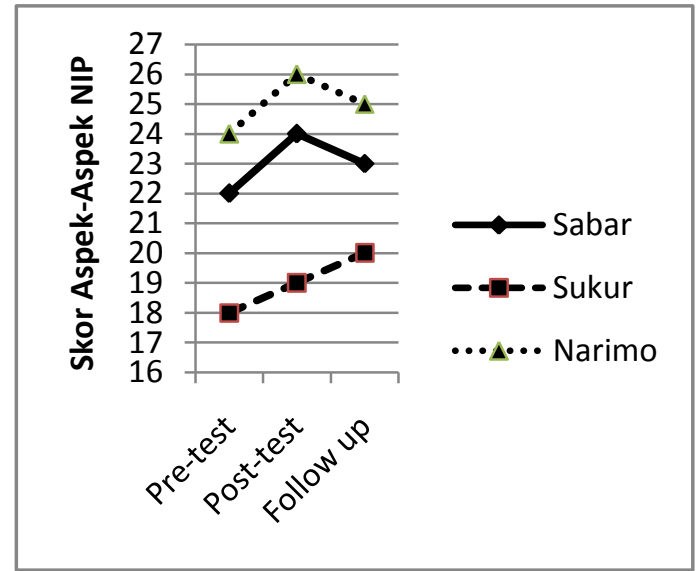

Gambar 2b

Gambar 2. Grafik Skor Sikap NIP (2a) dan Skor Aspek NIP (2b) EN

Pengukuran aspek-aspek sikap NIP menunjukkan peningkatan aspek sukur dari kategori sangat rendah saat prates menjadi kategori rendah saat pascates dan meningkat menjadi kategori sedang pada saat tindak lanjut. Sedangkan aspek sabar dan narima menunjukkan peningkatan dari kategori rendah pada prates menjadi kategori sedang pada pascates namun kembali rendah saat tindak lanjut. Perubahan sikap NIP harian juga menunjukkan trend peningkatan selama berlangsungnya intervensi. 


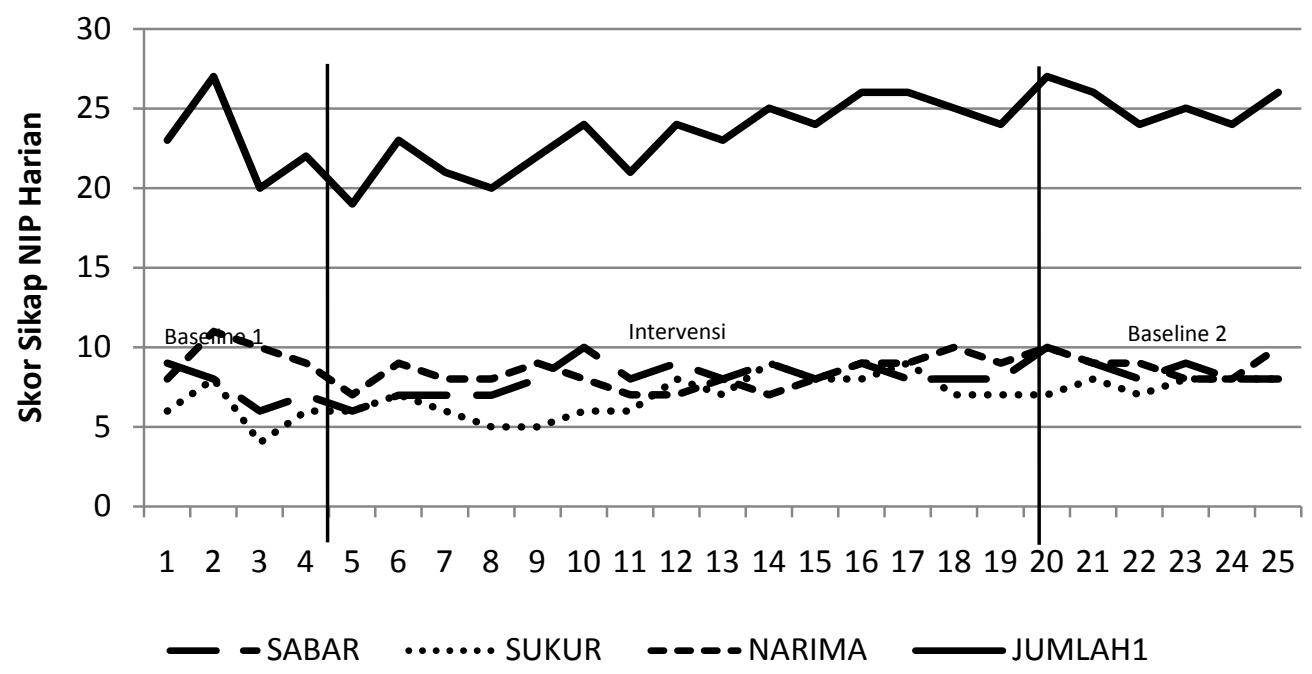

Gambar 3. Grafik Perubahan Sikap NIP Harian EN

Data kualitatif yang dikumpulkan menggambarkan bagaimana proses perubahan yang dialami oleh EN. Selama berjalannya pertemuan pertama (psikoedukasi skizofrenia dan NIP), EN beberapa kali mengernyitkan dahi saat fasilitator menjelaskan padanya tentang skizofrenia dan NIP. Di saat fasilitator menjelaskan tentang perasaan yang umumnya dialami oleh family caregiver ODS, EN mengatakan "Iha nggih ngaten niku.." (iya seperti itu) dengan nada yang agak tinggi. Seringkali EN mengatakan, "nggih..nggih leres sanget niku.." (уа..ya.. benar sekali itu). EN mengatakan bahwa semua gejala skizofrenia yang dijelaskan memang ada pada suaminya. la tahu bahwa sikap NIP memang baik dan sering dikatakan oleh simbah-simbahnya dulu. Tetapi EN bingung bagaimana harus bersikap seperti itu sementara kenyataan hidupnya cukup pahit. Berdasarkan penja- baran di atas terlihat bahwa EN memperhatikan dan berusaha memahami materi yang diberikan.

Pada pertemuan kedua (psikoedukasi sabar), EN mengaku bahwa selama ini dirinya telah berusaha bersabar walaupun sulit untuk dilakukan. Menurut $\mathrm{EN}$, hal ini terjadi karena ia harus menanggung beban hidup yang cukup berat. Ketika disampaikan materi tentang nyebar godhong koro, EN terlihat menangis. Ia mengatakan bahwa Gusti Allah yang akhirnya bisa menguatkannya. Saat mengikuti sesi semadi (meditasi), EN dapat mengikuti setiap instruksi yang diberikan dengan baik. EN mengatakan bahwa dirinya merasa lebih plong dan dadanya semriwing saat mengakhiri semadi.

Pertemuan ketiga (psikoedukasi sukur) dimulai dengan obrolan singkat antara fasilitator dan EN. EN menceritakan 
bahwa sehari yang lalu ia telah mencoba bersabar. la tidak memaksa ketika ODS menolak diajak mburuh ke sawah. Walaupun demikian, sebenarnya ia sedih melihat ODS hanya bermalas-malasan di rumah. Saat fasilitator menjelaskan materi sukur, EN tampak bersandar di kursi dan mengangguk-anggukkan kepalanya. Ketika fasilitator selesai menyampaikan materi ana udan ana panas, EN terlihat beberapa kali menarik nafas dalam. Menurut EN, yang membuatnya bersyukur adalah kondisi anak-anaknya yang waras. EN dapat mengikuti instruksi fasilitator selama sesi meditasi berlangsung. Pada saat meditasi selesai, EN mengatakan "kraos seneng mbak.." (merasa senang mbak). Saat ditanya lebih lanjut, ia hanya terlihat tersenyum dan bersandar di kursinya.

Pada pertemuan keempat (psikoedukasi narima), EN bercerita bahwa tadi pagi ODS dan anaknya bertengkar. Anaknya merasa jengkel karena bukunya ditaruh di teras oleh ODS sehingga kehujanan. Pertengkaran tersebut mereda setelah anaknya melihat EN menangis. Di pertemuan ini, EN banyak bercerita tentang bagaimana lelahnya ia menghadapi perilaku ODS sekaligus sikap anaknya terhadap ODS. EN menyadari bahwa ia bukan hanya menjadi pendamping bagi ODS, tetapi menjadi penengah antara ODS dan anaknya. EN mengatakan bahwa dirinya merasa senang karena dapat berbagi cerita dengan fasilitator tentang beban hidup yang sekian tahun hanya bisa ia pendam. Saat capek dan lelah menjalani kehidupan, EN mengatakan, "nggih namung ngunjal ambegan mawon koyo sik pun diajari mbake niko, lajeng kraos rodo cumeplong ngaten.." (ya..menarik nafas dalam-dalam seperti yang pernah mbak ajarkan dahulu, terus rasanya jadi agak lega gitu...).

Di pertemuan terakhir (penutup), EN mengaku bahwa ia telah mempelajari banyak hal. EN mulai paham bagaimana cara mendampingi ODS sekaligus menerapkan sikap NIP seperti pitutur orang tua dan simbahnya dahulu. Akhir-akhir ini ia merasa lebih nyaman setelah berusaha memasrahkan semuanya kepada Tuhan. EN mengatakan "mpun mbak, wong Gusti mboten tilem mawon kok.." (sudah mbak, kan Tuhan tidak tidur).

\section{Partisipan SR}

Kondisi awal menunjukkan tingginya beban yang dirasakan SR. ODS mengalami sakit sejak delapan tahun yang lalu. SR menjelaskan cerita awal mula ODS sakit. ODS pernah bekerja sebagai buruh bangunan di Jakarta selama empat bulan. Dua minggu setelah pulang, ODS tiba-tiba mengamuk dan melempari kaca tetangganya. Hal ini menyebabkan warga membawa ODS ke RSJ Grhasia. Setelah opname beberapa bulan, ODS menjalani rawat jalan. ODS kemudian kembali bekerja sebagai buruh bangunan di Jakarta. Setelah sembilan bulan bekerja di Jakarta, ODS diantar pulang oleh temannya dalam kondisi bingung. Selain menjadi mudah marah, ODS juga mengaku sebagai tuan tanah sekelurahan. ODS sudah tiga kali dirawat di RSJ Grhasia. Menurut SR, 
selama menjalani rawat jalan ODS jarang minum obat. ODS akan marah jika SR mengingat-kannya.

SR merasa malu dengan anggapan masyarakat bahwa suaminya edan taun. Setiap hari SR bekerja sebagai pembantu rumah tangga di perumahan dekat kampungnya. la bekerja dari jam tujuh pagi sampai lima sore sementara ODS dirawat oleh anak laki-lakinya di rumah. SR sering pulang kerja setelah maghrib walaupun sebenarnya jam kerjanya hanya sampai jam lima sore. Hal ini ia lakukan untuk menghindari warga yang sering duduk-duduk di pinggir jalan kampung pada sore hari. SR merasa malu dengan tingkah laku ODS selama ini. Ingin rasanya ia marah dan memaki ODS, tetapi takut. Yang ia lakukan adalah memendamnya.

Hasil analisis perubahan kondisi SR melalui visual inspection menunjukkan adanya peningkatan kesejahteraan psikologis selama pelaksanaan intervensi dari kategori rendah menjadi sedang, namun kembali menurun menjadi kategori rendah pada saat tindak lanjut.

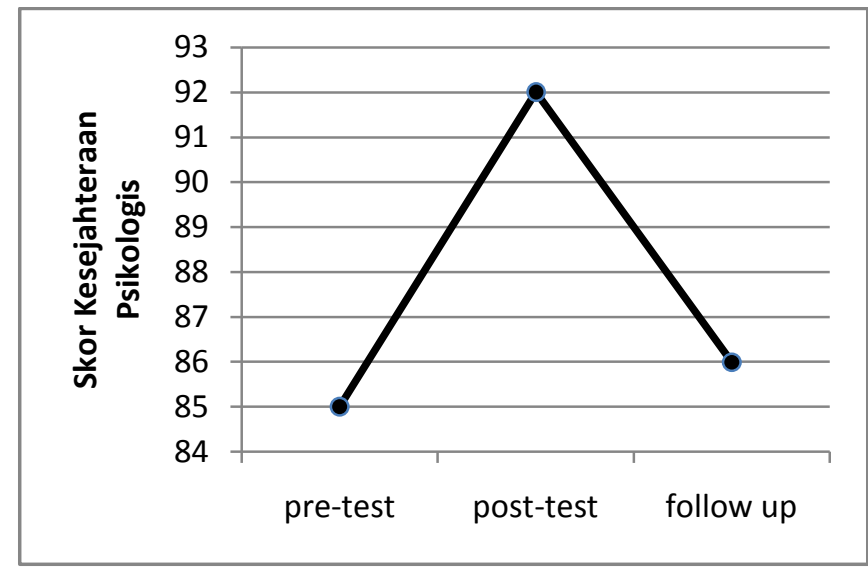

Gambar 4. Grafik Skor Kesejahteraan Psikologis SR

Partisipan menunjukkan peningkatan sikap NIP dari kategori sangat rendah pada saat prates menjadi kategori sedang pada pascates. Tingkatan sikap NIP dalam kategori sedang tersebut bertahan sampai saat tindak lanjut walaupun mengalami penurunan sebesar satu poin. 


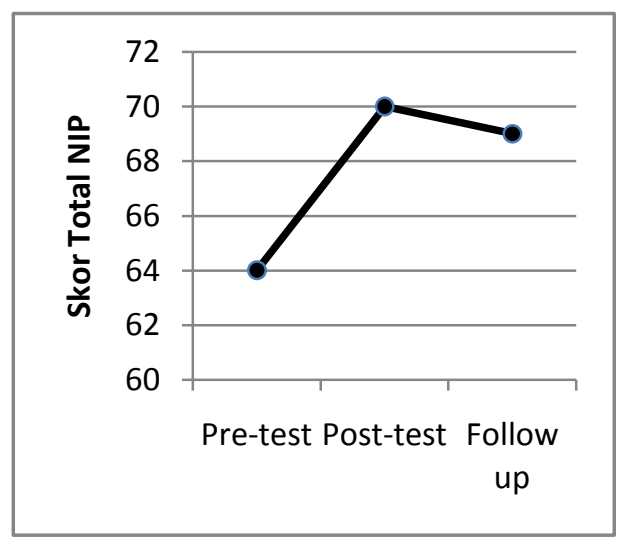

Gambar 5a

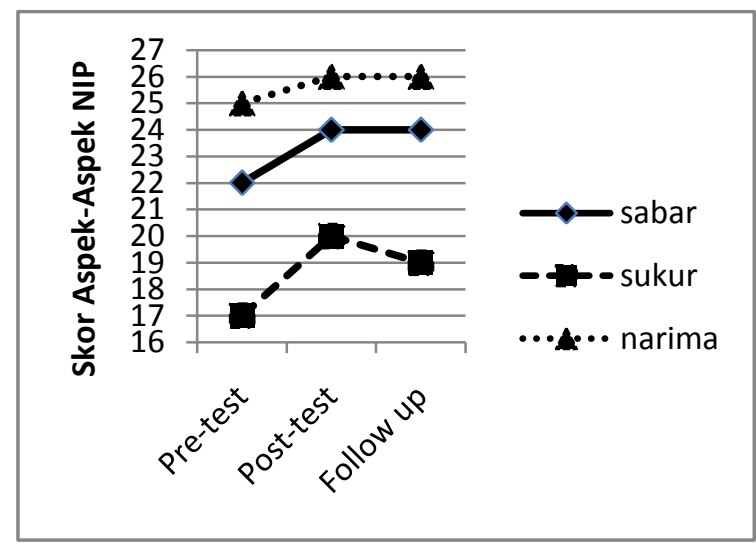

Gambar 5b

Gambar 5. Grafik Skor Sikap NIP (5a) dan Skor Aspek NIP (5b) SR

Pengukuran aspek-aspek sikap NIP menunjukkan peningkatan aspek sukur dari kategori sangat rendah pada prates menjadi kategori sedang saat pascates namun menurun ke tingkatan rendah pada tindak lanjut. Sedangkan aspek sabar dan narima menunjukkan peningkatan dari kategori rendah pada prates menjadi kategori sedang pada pascates yang bertahan hingga tindak lanjut. Selain itu, tampak perubahan sikap NIP harian yang menunjukkan trend peningkatan selama berlangsungnya intervensi.

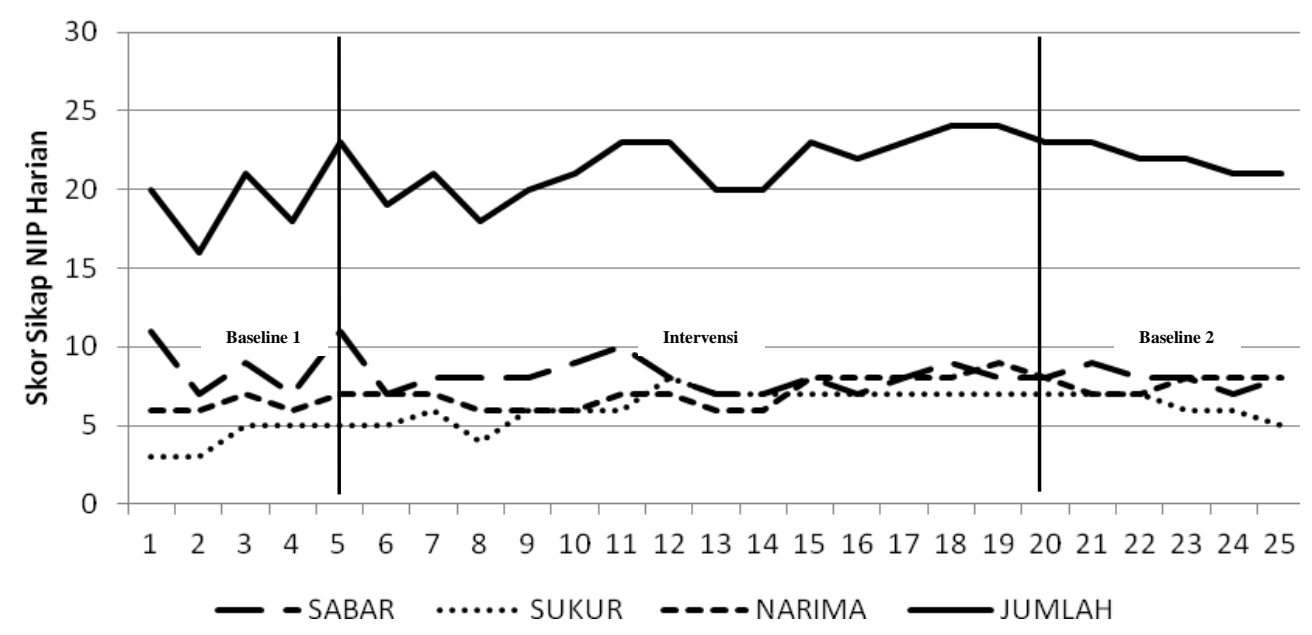

Gambar 6. Grafik Perubahan Sikap NIP Harian SR

Data kualitatif menunjukkan bahwa pada pertemuan pertama (psikoedukasi skizofrenia dan NIP), SR tampak beberapa kali mengangguk dan menceritakan beberapa hal yang berhubungan dengan skizofrenia. SR sudah tahu tentang sikap NIP 
dari pengajian yang setiap selapanan (35 hari sekali) ia ikuti. Walaupun demikian, sikap tersebut sulit ia lakukan mengingat beban hidupnya yang sangat berat. SR menjadi tahu berbagai penjelasan tentang sakit yang dialami ODS. SR juga mengetahui bahwa ada penjelasan medis mengenai penyakit ODS. SR mengatakan bahwa informasi yang ia dapatkan hari ini sangatlah berguna. SR berencana untuk meneruskan informasi tersebut kepada anaknya, terutama poin mengenai pentingnya obat bagi ODS. Selain itu, SR pun paham mengenai sikap NIP yang akan ia terapkan dalam kehidupan walaupun menurutnya cukup berat untuk dilakukan.

SR mengikuti pertemuan kedua (psikoedukasi sabar) dengan seksama. Menurut SR, ia cukup memahami penjelasan fasilitator dan akan mencoba untuk menerapkannya dalam kehidupan seharihari. Selama sesi meditasi, SR dapat mengikuti setiap instruksi yang disampaikan fasilitator dengan baik. Setelah meditasi selesai, SR mengatakan "wah.. .awake mindhak entheng mbak.." (wah... badanku terasa makin ringan mbak).

Pada pertemuan ketiga (psikoedukasi sukur), fasilitator menyampaikan materi ana udan ana panas. Setelah fasilitator selesai menyampaikan materi, sambil menangis SR mengatakan bahwa yang membuat dirinya bersyukur adalah kehadiran anak-anaknya yang rajin sholat dan waras. Sebagai tulang punggung perekonomian keluarga, SR tidak dapat memba- yangkan apa yang akan terjadi jika anaknya ikut-ikutan sakit seperti ODS.

Pada awal pertemuan keempat (psikoedukasi narima), SR mengatakan bahwa sejak kemarin sore ODS tidak bersedia minum obat dan hanya bermalas-malasan saja di rumah. Hal seperti itu membuatnya jengkel, gregetan dan bingung menerima kenyataan yang berulang kali terjadi. SR hanya bisa memendam perasaan-perasaan tersebut karena malu untuk berkeluhkesah dengan orang lain. SR setuju dengan materi sedaya sampun kersaning Gusti yang disampaikan oleh fasilitator. SR mengatakan bahwa dirinya sadar posisinya sebagai garwa yang menurutnya berarti sigaraning nyawa (belahan jiwa). Apapun yang terjadi, ia akan mencoba menghadapinya dengan berusaha tabah walaupun cukup berat untuk dilakukan.

Di pertemuan terakhir (penutup), SR menyampaikan terima kasih kepada fasilitator, "matur nuwun nggih mbak malah kulo sambati terus.." (terima kasih ya mbak malah saya curhati terus). SR mengaku selama ini dirinya cenderung memendam setiap perasaan tidak nyaman yang muncul. SR juga telah mengetahui bagaimana cara mendampingi ODS dan akan mencoba menerapkan sikap NIP dalam kehidupan sehari-hari.

\section{PEMBAHASAN}

Hasil penelitian menunjukkan bahwa selama proses intervensi, kedua partisipan mengalami peningkatan kesejah- 
teraan psikologis. Peningkatan kesejahteraan psikologis tersebut didukung oleh adanya peningkatan sikap NIP serta sikap NIP harian selama intervensi berlangsung. Adanya peningkatan kesejahteraan psikologis selama intervensi menandakan program intervensi NIP mampu meningkatkan sikap NIP kedua partisipan. Hal ini sejalan dengan Dorian dkk (2008) serta Martens dan Addington (2001) yang menyatakan bahwa kurangnya sikap penerimaan akan meningkatkan kondisi stressful family caregiver yang berdampak pada menurunnya kesejahteraan psikologis. Semakin rendah stres dan semakin banyak informasi atau pengalaman positif akan meningkatkan kepuasan hidup (Diener, Frank, Tay, \& Biswas, 2011).

Chakrabarti dan Gill (Chadda, Singh, \& Granguly (2007) menyatakan bahwa beban psikologis yang menumpuk hadir karena tindakan menghindar atau lari dari masalah. Saat merasa sudah tidak kuat lagi menahan perasaan tidak nyaman karena tingkah laku ODS, EN cenderung menghindarinya dengan tidur. Sedangkan SR sering pulang kerja setelah maghrib karena malu dengan tetangga desanya yang pada sore hari banyak nongkrong di pinggir jalan desa, padahal sebenarnya jam kerja SR hanya sampai jam lima sore. Dalam program intervensi NIP, partisipan tidak diarahkan untuk menghindari masalah tetapi difasilitasi untuk mendekati, menerima, dan memahami permasalahannya. Kedua partisipan diajak untuk mengupas permasalahan perlahan-lahan dan mendiskusikan langkah-langkah pe- nyelesaiannya. Mereka diajarkan bagaimana caranya untuk menjadi pendamping yang tangguh dengan melakukan beberapa aktifivitas manajemen stress dan menerapkan sikap NIP dalam kehidupannya.

Selama proses intervensi, kedua partisipan difasilitasi untuk mengungkapkan dan mengekspresikan beban emosi dan perasaan yang selama ini mereka pendam. Pengungkapan beban emosi (self disclosure) merupakan sebuah proses di mana seseorang memberikan informasi secara verbal tentang siapa dirinya kepada orang lain, seperti perasaan tidak nyaman atau bahkan trauma yang pernah dialami (Derlega, Metts, Petronio, \& Margulis, 1993; Robert, 2005). Pelepasan emosi yang tertahan dapat menimbulkan efek terapeutik sehingga akan memunculkan rasa nyaman dan meningkatkan kesejahteraan (well being) (Corsini \& Wedding, 1989; Pennebaker, 2002). Saat intervensi berakhir, fasilitator tidak dapat lagi memfasilitasi pelepasan emosi secara langsung seperti yang dilakukan pada saat intervensi. Hal ini cukup memengaruhi sikap penerimaan partisipan yang menyebabkan kesejahteraan psikologisnya menjadi berkurang. Peran terapis sangat diperlukan untuk dapat memfasilitasi pelepasan emosi secara langsung sehingga terjadi penguatan psikologis klien dalam menerima situasi dan kondisi menekan di sekitarnya (Robert, 2005).

Pada saat intervensi selesai dilaksanakan (follow up), kesejahteraan psikologis kedua partisipan mengalami penu- 
runan. Hal ini selaras dengan penurunan sikap NIP dan perubahan sikap NIP harian yang juga menunjukkan trend penurunan. Chakrabarti (2011) menegaskan bahwa salah satu kebutuhan pendamping yang paling utama adalah keberadaan dukungan motivasi dan emosi bagi pendamping selama proses pendampingan. Keberadaan fasilitator yang memotivasi dan memberikan dukungan emosi secara kuat dan intens menjadi sebuah kekuatan tersendiri bagi kedua partisipan dalam menerima serta menghadapi masalahnya. Kenyataan setelah intervensi berakhir, partisipan tidak lagi mendapatkan dukungan emosi serta motivasi secara langsung dari fasilitator.

Dalam analisis per aspek NIP, walaupun terjadi penurunan sikap NIP pada saat tindak lanjut, tetapi EN menunjukkan peningkatan aspek sukur selama pengukuran lintas waktu prates, pascates dan tindak lanjut. Sedangkan pada SR, aspek sabar dan narima dapat bertahan sampai masa setelah intervensi berakhir. Hal tersebut terjadi karena adanya makna yang lebih tinggi pada partisipan sebagai pendamping ODS. Makna yang lebih tinggi ini dapat diartikan sebagai purpose in life, yaitu manifestasi dari nilai-nilai inti dan perhatian yang memberikan kerangka psikologis untuk mencapai tujuan (Kashdan, dalam Diener dkk, 2011).

Makna hidup (purpose in life) memiliki peran yang sangat penting sebagai bekal mengarungi kehidupan. Bagi orang Jawa, kehidupan digambarkan dalam dunia wayang sebagai sebuah gunungan. Gunungan memiliki peran dan fungsi yang penting dalam pertunjukan wayang. Kedudukan seperti itu tampak pada gunungan yang selalu ditempatkan di tengah pada awal dan akhir pertunjukan. Gambar gunungan dilukiskan sebagai berikut: pada bagian separuh atas gunungan terdapat cabang-cabang pohon kehidupan yang tersebunyi di balik pintu. Binatang kera dan burung berada di antara cabang-cabang pohon tersebut. Dua ular dan binatang besar seperti harimau dan banteng terlihat berhadapan satu sama lain. Pada bagian bawah gunungan terdapat dua raksasa yang menjaga pintu, lantai, pilar dan bunga padma. Gambaran warna-warni tersebut merupakan simbol tatanan kosmik, pertumbuhan, kehidupan, dan lain sebagainya.

Refleksi filosofis tentang gunungan memberikan pencerahan pada konsep manusia, eksistensinya di dunia, serta beberapa konsekuensi religius dan etik bagi sikap dan perilaku manusia. Gunungan memuat beberapa gagasan filosofis struktur eksistensi manusia yang dikenal dengan konsep sangkan paraning dumadi (keberadaan manusia merupakan hasil dari ciptaan Tuhan Yang Maha Pencipta yang kelak pada akhirnya juga akan kembali kepada-Nya). Keberadaan manusia di dunia fana ini (alam madya) dipandang sekedar singgah dari perjalanannya yang dimulai dari alam awal (alam purwa) yang nantinya akan menuju ke alam akhir, alam kelanggengan (alam 
wusana). Kehidupan manusia di dunia fana ini diibaratkan dengan ungkapan prasasat urip iku koyo wong mampir ngombe, yang menunjukkan betapa singkatnya waktu manusia hidup di dunia ini dibandingkan dengan kehidupan di alam keabadian.

Konsep sangkan paraning dumadi, setiap episode dalam kehidupan manusia tidak lepas dari campur tangan Tuhan. Hal tersebut tumbuh seiring dengan keyakinan bahwa manungsa sakdrema nglakoni urip (manusia hanya sekedar menjalani hidup) dan Gusti kang wenang nemtoake (Tuhan yang berwenang menentukan). Menurut Aksan (1995), Darmanto (2007) serta Suratno dan Astiyanto (2009), keyakinan bahwa manusia hanya menjalani kehidupan serta Tuhan yang menentukan disebut narima. Keyakinan akan kuasa Tuhan inilah yang peneliti temukan dalam ungkapan Gusti ora sare dan Garwa dari kedua partisipan. EN menilai bahwa seburuk apapun kondisi yang dihadapi tetapi ia meyakini bahwa Gusti ora sare (Tuhan selalu mengawasi dan mengasihi). Sedangkan SR menyatakan bahwa dirinya sadar posisinya sebagai garwa ODS yang menurutnya berarti sigaraning nyawa (belahan jiwa). Apapun yang terjadi, ia akan mencoba menghadapinya dengan berusaha tabah walaupun terasa berat untuk dilakukan. Kekuatan keyakinan terhadap kuasa Tuhan (religious coping) memainkan peran penting dalam mempertahankan sikap narima sehingga kesejahteraan psikologis akan terjaga selama mendampingi ODS pasca intervensi (Rammohan, Rao, \& Subbakrishna, 2002).

Hal-hal yang ikut memengaruhi keberhasilan penelitian ini antara lain karena intervensi psikoedukasi telah terbukti efektif untuk family caregiver ODS dalam meningkatkan sikap penerimaan, strategi koping, kualitas pendampingan dan well being (Oshodi, 2012; Navidian dkk, 2012; Drapalsky dkk, 2009). Pelaksanaan intervensi secara individual melalui kunjungan rumah (homedelivered) memberikan dampak yang lebih besar karena memunculkan rasa diperhatikan, dipahami, dan dihargai sehingga tidak saja menjadi dukungan sosial dalam bentuk informasi dan instrumen namun juga emosi.

\section{SIMPULAN DAN SARAN}

\section{Simpulan}

Dari penelitian ini dapat disimpulkan bahwa program intervensi NIP dapat meningkatkan kesejahteraan psikologis family caregiver ODS selama intervensi dilaksanakan. Peningkatan kesejahteraan psikologis ditandai dengan meningkatnya sikap NIP kedua partisipan. Penurunan kesejahteraan psikologis pada tahap tindak lanjut selaras dengan menurunnya sikap NIP setelah berakhirnya intervensi. Hal ini disebabkan tidak adanya lagi dukungan emosi dan sosial secara langsung serta media self disclosure bagi family caregiver ODS. 


\section{Saran}

Program intervensi NIP ini dapat dijadikan sebagai salah alternatif terapi bagi keluarga pasien skizofrenia untuk meringankan beban psikologis mereka, dengan beberapa penyesuaian. Misalnya tugas buku harian cukup menyulitkan partisipan untuk menuliskan perasaan dan pengalamannya setiap hari bagi keluarga yang memiliki tingkat pendidikan yang rendah. Selain itu program ini perlu ditambah waktu untuk pertemuan antara fasilitator dengan keluarga pasien ODS. Mereka membutuhkan waktu lebih lama sebelum mereka dapat mandiri dalam menerapkan sikap narimo ing pandum.

\section{DAFTAR PUSTAKA}

Aksan. (1995). Ilmu dan laku Drs. R.M.P. Sosrokartono. Surabaya : Citra Jaya Murti.

Ambikile, J.S., Outwater A. (2012). Challenges of Caring for Children with Mental Disorders: Experiences and Views of Caregivers Attending The Outpatient Clinic at Muhimbili National Hospital, Dar es SalaamTanzania. Children and Adolescent Psychiatry and Mental Health, 6, 16.

Bloch, S., Scmukler, G.I., Herrman, H., \& Colussa, S. (1995). Counseling Caregivers of Relatives with Schizophrenia: Themes, Interventions, and Caveats. Family Process, 34, 413425.
Broto, A.A.W. (1994). Efek Pelatihan Meditasi Transendental terhadap Penerimaan Diri. Skripsi (Tidak Diterbitkan). Yogyakarta : Fakultas Psikologi UGM.

Casmini. (2011). Kecerdasan Emosi dan Kepribadian Sehat Dalam Konteks Budaya Jawa di Yogyakarta. Disertasi (Tidak Diterbitkan). Yogyakarta: Program Doktor Psikologi Fakultas Psikologi UGM.

Chadda, R.K., Singh, T.B., \& Granguly, K.K. (2007). Caregiver Burden and Coping: A Prospective Study of Relationship Between Burden and Coping In Caregivers of Patients With Schizophrenia and Bipolar Affective Disorder. Social Psychiatry and Epidemiology, 42, 923930.

Chakrabarti, S. (2011). Family Intervention in Schizoprenia : Issues of Relevance for Asian Countriies. World Journal of Psychiatry, 1(1), 4-7.

Corsini, R.J. \& Wedding, D. (1989). Current Psychotherapy. Fourth Edition. Illinois: F.E. Peacock Publisher, Inc

Darmanto, J. (2007). Psikologi Jawa. Yogyakarta: Yayasan Bentang Budaya.

Davis, M., Eshelman, E.R dan Matthew, M. (1995). Panduan Relaksasi dan Reduksi Stres Edisi III. Jakarta: Penerbit Buku Kedokteran EGC. 
Davis, L.W., Strasburger, A.M., \& Brown, L.F. (2007). Mindfulness: An Intervention for Anxiety in Schizophrenia. Journal of Psychososial Nursing, 45(11), 23-29.

Derlega, V., Metts S., Petronio, S., \& Margulis, S.T. (1993). Self Disclosure. California: Sage Publication, Inc.

Dharmawati. (2011). Psychological Well Being Wanita Lajang. Skripsi (Tidak Diteritkan). Yogyakarta: Fakultas Psikologi UGM.

Diener, E., Frank, F., Tay, L., \& BiswasDiener, R. (2011). Purpose, Mood, and Pleasure in Predicting Satisfaction Judgement. Social Indicator Research, 15, 187-219.

Dorian, M., Garcia, J.I.R., Lopez, S.R. \& Hernandez, B. (2008). Acceptance and Expressed Emotion in Mexican American Caregivers of Relatives with Schizophrenia. Family Process, 47(2), 215-228.

Drapalsky, A. L., Leith, J., \& Dixon, L. (2009). Involving Families in the Care of Persons with Schizophrenia and Other Serious Mental Illnesses : History, Evidence, and Recommendations. Clinical Schizophrenia \& Related Psychoses, 3, 39-49.

Emmons, R.A., \& McCullough, M.E. (2003). Counting Blessing Versus Burdens: An Experimental Investigation of Gratitude and Subjective Well Being in Daily Life. Journal of
Personality and Social Psychology, 84 (2), 377-389.

Endraswara, S. (2012). Falsafah Hidup Jawa: Menggali Mutiara Kebijakan dari Intisari Filsafat Kejawen. Yogyakarta: Cakrawala.

Fananie, Z. (2005). Restrukturisasi Budaya Jawa Perspektif KGPAA MN I. Surakarta: Muhammadiyah University Press.

Grandon, P., Jenaro, C., \& Lemos, S. (2008). Primary Caregiver of Skizofrenia Outpatients : Burden and Predictor Variables. Journal of Psychiatry, 158, 335-343.

Greenberg, J.S. (2002). Comprehensive Stress Management. New York : McGraw-Hill Co.

Hawari, D. (2003). Pendekatan Holistik Pada Gangguan Jiwa Skizofrenia. Jakarta: Balai Penerbit FKUI.

Hardjoprakoso. (1971). Serat Sasangka Djati. Surakarta: Pangestu.

Hardjowirogo, M. (1989). Manusia Jawa. Jakarta: CV Haji Mas Agung.

Huppert, F.A., Baylis, N., \& Keverne, B. (2005). The Science of Well-Being. New York: Oxford University Press Inc.

Koentjaraningrat. (1990). Pengantar Ilmu Antropologi. Jakarta : Rineka Cipta.

Koeswardhani, T.E. (2011). Terapi Pemaafan Untuk Menurunkan Beban Partisipatif Pendamping 
Penderita Skizofrenia. Tesis (Tidak Diterbitkan). Yogyakarta: Fakultas Psikologi UGM.

Martiarini N. (2012). Pengatasan Kelelahan Ego (Ego Depletion) Pada Individu Dalam Konteks Budaya Jawa. Tesis (Tidak Diterbitkan). Yogyakarta: Fakultas Psikologi UGM.

Martens, L., \& Addington, J. (2001). The Psychological Well Being of Family Members of Individuals with Schizoprenia. Social Psychiatry and Psychiatric Epidemiology, 36(3), 128-133.

Matsumoto, D. (2004). Pengantar Psikologi Lintas Budaya (Terjemahan). Yogyakarta : Pustaka Pelajar.

McKenzie, J.F., Penger, R.R., \& Kotecki, J.E. (2006). Kesehatan Masyarakat Suatu Pengantar. Jakarta : Buku Kedokteran UI.

Mulyana. (2006). Spiritualitas Jawa: Meraba Dimensi dan Pergulatan Religiusitas Orang Jawa. Jurnal Kebudayaan Jawa, 1(2), 1-13.

Navidian, A., Kemansaravi, F., \& Rigi, S. N. (2012). The Effectiveness of a Group Psycho-educational Program on Family Caregiver Burden of Patients with Mental Disorder. BMC Research Notes, 5(399), 2-7.

Oshodi, Y., Adeyemi, J., Alna, O. S., \& Umeh, C. (2012). Burden and Psychological Effects : Caregiver Experiences in a Psychiatric Outpa- tient Unit in Lagos, Nigeria. African Journal of Psychiatry, 15, 99-105.

Pennebaker, J.W. (2002). Opening Up: The Healing Power of Expressing Emotion. New York: Guilford Press.

Puspasari, D. (2012). Pelatihan Ketrampilan Komunikasi Untuk Menurunkan Expressed Emotion Keluarga Penderita Skizofrenia. Tesis (Tidak Diterbitkan). Yogyakarta : Fakultas Psikologi UGM.

Rachmatullah, A. (2010). Falsafah Hidup Jawa. Yogyakarta: Logung Pustaka.

Rahardjo, T., (2005). Menghargai Perbedaan Kultural. Yogyakarta: Pustaka Pelajar.

Rammohan, A., Rao, K., \& Subbakrishna, D.K. (2002). Religious Coping and Psychological Well-Being in Carers of Relatives with Schizophrenia. Acta Psychiatrica Scandinavica, 105(5), 356-362.

Renoati, W.I. (2006). Hubungan Antara Penghayatan Nilai Narima Ing Pandum dan Semangat Berkompetisi Karyawan Jawa. Skripsi (Tidak Diterbitkan). Yogyakarta: Fakultas Psikologi UGM.

Robert, J. (2005). Transparency and SelfDisclosure in Family Therapy: Dangers and Possibilities. Family Process, 44(1), 45-63.

Ryff, C.D. (1989). Happiness Is Everything or Is It? : Explorations on The Meaning of Psychological Well- 
Being. Journal of Personality \& Social Psychology, 57, 1069-1081.

Ryff, CD., \& Keyes, CLM. (2002). The Structure of Psychological Well Being Revisited. Journal of Personality and Social Psychology, 69(4), 719-727.

Sastroamidjojo, Seno. (1972). Gagasan Hakekat Hidup Manusia Jawa. Jakarta: Bharata.

Schene, A.H., Wijngaarden, B.V., \& Koeter, M.W.J. (1998). Family Caregiving in Schizophrenia: Domains and Distress. Schizophrenia Bulletin, 24(4), 609-618.

Schultz, R. \& Sherwood, P.R. (2008). Physical and Mental Health Effects of Family Caregiving. Journal of Social Work Education, 44, 105113.

Soesilo. (2003). Piwulang Ungkapan Orang Jawa. Jakarta: Yayasan Yusula.

Stern, S., Doolan, M., Staples, M., Szmukler, G.L. \& Eisler, I. (1999). Disruption and Rekonstruction : Narrative Insight into the Experience of Family Members Caring for a Relative Diagnosed with Serious Mental Illness. Family Process, 38(3), 353-369.
Subandi. (2011). Sabar: Sebuah Konsep Psikologi. Jurnal Psikologi UGM, 3(2), 215-227.

Suratno, P. \& Astiyanto, H. (2009). Gusti Ora Sare : 90 Mutiara Nilai Kearifan Budaya Jawa. Yogyakarta : Adiwacana.

Syamsuri. (2011). Perilaku Keluarga Terhadap Penerimaan Pasien Skizofrenia di Wilayah Kerja Puskesmas Banda Raya Kota Banda Aceh Pemerintah Aceh. Tesis (Tidak Diterbitkan). Yogyakarta: Progam Pascasarjana Universitas Gadjah Mada.

Talwar, P. \& Matheiken, S.T. (2010). Caregivers in Schizophrenia: A Cross Cultural Perspective. Indian Journal Psychology Medical, 32(1), 29-33.

Widayat, A. (2006). Metruk: Menyuarakan Karakter Orang Jawa. Jurnal Kebudayaan Jawa, 1(2), 79-90.

White, T.M., Gibbons, C., Connoly Gibbons, M.B., Scamberger, M. (2006). Cultural Sensitivity and Supportive Expressive Psychotherapy: An Integrative Approach to Treatment. American Journal of Psychotherapy, 60(3), 299-316. 